\title{
Enhancement of nutrient removal from swine wastewater digestate coupled to biogas purification by...
}

Article in Bioresource Technology · December 2015

DOI: 10.1016/j.biortech.2015.11.082

CITATIONS

14

6 authors, including:
READS

101

\section{Jean Michel Prandini}

Federal University of Santa Catarina

15 PUBLICATIONS 18 CITATIONS

SEE PROFILE

\section{Melissa Paola Mezzari}

Rice University

44 PUBLICATIONS 160 CITATIONS

SEE PROFILE

\section{Marcio Luis Busi Da Silva}

Brazilian Agricultural Research Corporation (... 68 PUBLICATIONS 642 CITATIONS

SEE PROFILE

\section{Mateus Pirolli}

Federal University of Santa Catarina

11 PUBLICATIONS 24 CITATIONS

SEE PROFILE

Some of the authors of this publication are also working on these related projects: 


\title{
Enhancement of nutrient removal from swine wastewater digestate coupled to biogas purification by microalgae Scenedesmus spp.
}

\author{
Jean Michel Prandini ${ }^{a}$, Márcio Luís Busi da Silva ${ }^{\mathrm{b}, *}$, Melissa Paola Mezzari ${ }^{\mathrm{c}}$, Mateus Pirolli $^{\mathrm{a}}$, \\ William Michelon $^{\mathrm{a}}$, Hugo Moreira Soares ${ }^{\mathrm{a}}$ \\ a Department of Chemical Engineering, Federal University of Santa Catarina, Florianópolis, SC 88040-900, Brazil \\ ${ }^{\mathrm{b}}$ EMBRAPA Swine and Poultry, P.O. Box 321, Concórdia, SC 89700-000, Brazil \\ ${ }^{\mathrm{c}}$ Biotechnology and Sciences Program, West University of Santa Catarina, Videira, SC 89560-000, Brazil
}

\section{H I G H L I G H T S}

- Biogas stimulates algae yield $1.1 \mathrm{~g}-\mathrm{DW} \mathrm{L} \mathrm{L}^{-1}$ and faster $\mathrm{NH}_{3}$ and $\mathrm{PO}_{4}{ }^{3-}$ removal.

- $\mathrm{H}_{2} \mathrm{~S}$ up to 3000 ppmv was not toxic and completely removed from biogas.

- $\mathrm{CO}_{2}$ is completely removed from raw biogas at $219.4 \pm 4.8 \mathrm{mg} \mathrm{L}^{-1} \mathrm{~d}^{-1}$.

- $\mathrm{O}_{2}$ up to $22 \% \mathrm{v} / \mathrm{v}$ in the filtered biogas can pose commercial restrictions.

- Filtered biogas can have up to $18 \%$ less $\mathrm{CH}_{4}$ decreasing its commercial value.

\section{A R T I C L E I N F O}

\section{Article history:}

Received 7 October 2015

Received in revised form 25 November 2015

Accepted 28 November 2015

Available online 5 December 2015

\section{Keywords:}

Biogas purification

Microalgae

Piggery wastewater

Tertiary treatment

\begin{abstract}
A B S T R A C T
This work investigated the effects of swine wastewater-derived biogas on microalgae biomass production and nutrient removal rates from piggery wastewater concomitantly with biogas filtration. Photobioreactors with dominant Scenedesmus spp. were prepared using non-sterile digestate and exposed to different photoperiods. In the presence of biogas and autotrophic conditions microalgae yield of $1.1 \pm 0.2 \mathrm{~g} \mathrm{~L}^{-1}$ (growth rate of $141.8 \pm 3.5 \mathrm{mg} \mathrm{L}^{-1} \mathrm{~d}^{-1}$ ) was obtained leading to faster $\mathrm{N}-\mathrm{NH}_{3}$ and $\mathrm{P}_{-} \mathrm{PO}_{4}^{3-}$ assimilation rate of $21.2 \pm 1.2$ and $3.5 \pm 2.5 \mathrm{mg} \mathrm{L}^{-1} \mathrm{~d}^{-1}$, respectively. $\mathrm{H}_{2} \mathrm{~S}$ up to $3000 \mathrm{ppmv}$ was not inhibitory and completely removed. Maximum $\mathrm{CO}_{2}$ assimilation of $219 \pm 4.8 \mathrm{mg} \mathrm{L}^{-1} \mathrm{~d}^{-1}$ was achieved. Biological consumption of $\mathrm{CH}_{4}$ up to $18 \% \mathrm{v} / \mathrm{v}$ was verified. $\mathrm{O}_{2}$ up to $22 \% \mathrm{v} / \mathrm{v}$ was controlled by adding acetate to exacerbate oxygen demand by microorganisms. Microalgae-based wastewater treatment coupled to biogas purification accelerates nutrient removal concomitantly producing valuable biomass and biomethane.
\end{abstract}

(c) 2015 Elsevier Ltd. All rights reserved.

\section{Introduction}

Agricultural wastewaters have been considered as an economical and alternative source of nutrients for production of micralgae in large scales. Cultivation of different microalgal strains are possible and throughout the cultivation process, nutrients are removed from wastewaters, thus serving as a tertiary treatment polishing step to reduce the risks associated with waterbodies eutrophication and other environment pollution implications (Ji et al., 2014). Many factors are known to affect microalgae biomass productivity in these systems such as carbon, light, and nutrients

* Corresponding author at: BR 153 Km 110, P.O. Box 321, 89000-700 Concórdia, SC, Brazil. Tel.: +55 49 34410400; fax: +55 4934410497 .

E-mail address: marcio.busi@embrapa.br (M.L.B. da Silva). sources, as well as the presence of microorganisms and predators that can act as competitors (Abinandan and Shanthakumar, 2015). Not surprisingly, microalgae culturing media augmented with different ratios of $\mathrm{CO}_{2}$, is shown to increment biomass productivity (for review see Table 1 ). $\mathrm{CO}_{2}$-rich gases can be obtained at low cost (e.g., flue gases) depending on the overall transportation logistics and distance from the source (Swarnalatha et al., 2015; Zhou et al., 2014). In agricultural areas, biodigesters are extensively used for reducing organic matter load from swine wastewater effluents through transformation of carbon into biogas as a sustainable and renewable source of fuel (Fuchsz and Kohlheb, 2015). Microalgae-based wastewater treatment process in these remote agricultural areas could benefit from the in situ $\mathrm{CO}_{2}$-rich biogas. Stimulation of microalgae production in this proposed platform could lead to increased yields and much faster nutrients 
Table 1

Effects of reactor type, culturing media, photoperiod, and gas feeding compositions on microalgae biomass growth rate, $\mathrm{CO}_{2}$ fixation and productivity.

\begin{tabular}{|c|c|c|c|c|c|c|c|c|}
\hline Microalga & Reactor type & $\begin{array}{l}\text { Culturing } \\
\text { media }\end{array}$ & $\begin{array}{l}\text { Gas feeding and } \\
\text { composition }(\% \mathrm{v} / \mathrm{v})\end{array}$ & Photoperiod & $\mu\left(\mathrm{d}^{-1}\right)$ & $\begin{array}{l}\text { Cell } \\
\text { productivity } \\
\left(\mathrm{mg} \mathrm{L}^{-1} \mathrm{~d}^{-1}\right)\end{array}$ & $\begin{array}{l}\mathrm{CO}_{2} \\
\text { assimilation } \\
\text { rate } \\
\left(\mathrm{mg} \mathrm{L}^{-1} \mathrm{~d}^{-1}\right) \\
\end{array}$ & References \\
\hline $\begin{array}{l}\text { C. vulgaris } \\
\text { Scenedesmus obliquus } \\
\text { C. vulgaris } \\
\text { Scenedesmus obliquus } \\
\text { C. vulgaris } \\
\text { Scenedesmus obliquus }\end{array}$ & Batch & $\begin{array}{l}\text { Sterile } \\
\text { domestic } \\
\text { digestate } \\
\text { effluent }\end{array}$ & $\begin{array}{l}\text { Headspace } \\
\text { containing biogas } \\
\left(61.4 \% \mathrm{CH}_{4} ; 32.6 \%\right. \\
\mathrm{CO}_{2} ; 0.54 \% \mathrm{O}_{2} ; \\
\left.\mathrm{H}_{2} \mathrm{~S}<50 \mathrm{ppmv}\right)\end{array}$ & $\begin{array}{l}16: 08 \\
14: 10 \\
12: 12\end{array}$ & $\begin{array}{l}0.35 \\
0.37 \\
0.39 \\
0.4 \\
0.32 \\
0.34\end{array}$ & $\begin{array}{l}89 \\
115 \\
139 \\
151 \\
73 \\
82\end{array}$ & $\begin{array}{l}167^{\mathrm{a}} \\
216^{\mathrm{a}} \\
261^{\mathrm{a}} \\
284^{\mathrm{a}} \\
137^{\mathrm{a}} \\
154^{\mathrm{a}}\end{array}$ & Wang et al. (2015) \\
\hline $\begin{array}{l}\text { Mutant strain of Chlorella } \\
\text { sp. }\end{array}$ & Batch & Synthetic & $\begin{array}{l}\text { Constant aeration } \\
\text { with air amended } 5 \% \\
\mathrm{CO}_{2} ; 100 \mathrm{ppm}_{2} \mathrm{~S} \\
\text { Constant aeration } \\
\text { with air amended } 5 \% \\
\mathrm{CO}_{2} ; 50 \mathrm{ppm}_{2} \mathrm{~S} \\
\text { Constant aeration } \\
\text { with air amended 5\% } \\
\mathrm{CO}_{2} \\
\text { Intermitent aeration } \\
\text { with } 70 \% \mathrm{CH}_{4} ; 20 \% \\
\mathrm{CO}_{2} ; \mathrm{H}_{2} \mathrm{~S}<100 \mathrm{ppm}\end{array}$ & $12: 12$ & - & $\begin{array}{l}241 \\
244 \\
276\end{array}$ & $\begin{array}{l}402.3^{\mathrm{a}} \\
453.1^{\mathrm{a}} \\
458.7^{\mathrm{a}} \\
524\end{array}$ & Kao et al. (2012b) \\
\hline $\begin{array}{l}\text { Mutant strain of Chlorella } \\
\text { sp. }\end{array}$ & Batch & Synthetic & $\begin{array}{l}\text { Constant aeration } \\
\text { with air amended } \\
20 \% \mathrm{CO}_{2} ; 100 \mathrm{ppm} \\
\mathrm{H}_{2} \mathrm{~S} \\
\text { Constant aeration } \\
\text { with air amended } \\
20 \% \mathrm{CO}_{2} ; 50 \text { ppm } \\
\mathrm{H}_{2} \mathrm{~S} \\
\text { Constant aeration } \\
\text { with air amended } \\
20 \% \mathrm{CO}_{2} \\
\text { Intermitent aeration } \\
\text { with } 69 \% \mathrm{CH}_{4} ; 20 \% \\
\mathrm{CO}_{2} ; \mathrm{H}_{2} \mathrm{~S}<50 \mathrm{ppm}\end{array}$ & $12: 12$ & - & 262 & $\begin{array}{l}454.9^{\mathrm{a}} \\
490.7^{\mathrm{a}} \\
492.6^{\mathrm{a}} \\
565.9^{\mathrm{a}}\end{array}$ & Kao et al. (2012a) \\
\hline $\begin{array}{l}\text { Chlorella pyrenoidosa } \\
\text { Chlorella pyrenoidosa }\end{array}$ & Batch & $\begin{array}{l}\text { Sterile swine } \\
\text { digestate } \\
\text { effluent with } \\
\text { pH } \\
\text { adjustments }\end{array}$ & $\begin{array}{l}\text { Constant aeration } \\
\text { with air } \\
\text { Constant aeration } \\
\text { with air amended } \\
15 \% \mathrm{CO}_{2}\end{array}$ & 24 & - & $\begin{array}{l}48.7 \\
85.6\end{array}$ & $\begin{array}{l}91.5^{\mathrm{a}} \\
160.9^{\mathrm{a}}\end{array}$ & Cheng et al. (2015) \\
\hline $\begin{array}{l}\text { C. vulgaris } \\
\text { S. obliquus } \\
\text { N. oleoabundans }\end{array}$ & Batch & $\begin{array}{l}\text { Sterile } \\
\text { domestic } \\
\text { digestate } \\
\text { effluent }\end{array}$ & $\begin{array}{l}\text { Headspace } \\
\text { containing biogas } \\
\left(61.32 \% \mathrm{CH}_{4} ; 34.45 \%\right. \\
\mathrm{CO}_{2} ; 0.62 \% \mathrm{O}_{2} ; \\
\left.\mathrm{H}_{2} \mathrm{~S}<50 \text { ppmv }\right)\end{array}$ & $12: 12$ & $\begin{array}{l}0.36 \\
0.45 \\
0.33\end{array}$ & $\begin{array}{l}112 \\
217 \\
86\end{array}$ & $\begin{array}{l}210.5^{\mathrm{a}} \\
407.9^{\mathrm{a}} \\
161.6^{\mathrm{a}}\end{array}$ & Zhao et al. (2015) \\
\hline Chlorella sp. & Batch & $\begin{array}{l}\text { Sterile } \\
\text { domestic } \\
\text { digestate } \\
\text { effluent }\end{array}$ & $\begin{array}{l}\text { Headspace } \\
\text { containing biogas } \\
\left(70.7 \% \mathrm{CH}_{4} ; 26.1 \%\right. \\
\mathrm{CO}_{2} ; 0.23 \% \mathrm{O}_{2} ; \\
\left.\mathrm{H}_{2} \mathrm{~S}<50 \mathrm{ppmv}\right)\end{array}$ & $\begin{array}{l}16: 08 \\
14: 10 \\
12: 12\end{array}$ & $\begin{array}{l}- \\
- \\
-\end{array}$ & $\begin{array}{l}47.7 \\
58.1 \\
28.8\end{array}$ & $\begin{array}{l}89.7^{\mathrm{a}} \\
109.2^{\mathrm{a}} \\
54.1^{\mathrm{a}}\end{array}$ & $\begin{array}{l}\text { Yan and Zheng } \\
\text { (2013) }\end{array}$ \\
\hline S. obliquus & Batch & $\begin{array}{l}\text { Sterile } \\
\text { diluted } \\
\text { swine } \\
\text { digestate }\end{array}$ & $\begin{array}{l}\text { Headspace } \\
\text { containing biogas } \\
\left(58.67 \% \mathrm{CH}_{4} ; 37.54 \%\right. \\
\mathrm{CO}_{2} ; 0.79 \% \mathrm{O}_{2} ; \\
\left.\mathrm{H}_{2} \mathrm{~S}<50 \text { ppmv }\right)\end{array}$ & $12: 12$ & $\begin{array}{l}0.48 \\
0.38\end{array}$ & $\begin{array}{l}124.4 \\
311.3\end{array}$ & $\begin{array}{l}233.8^{\mathrm{a}} \\
585.2^{\mathrm{a}}\end{array}$ & Xu et al. (2015) \\
\hline Desmodesmus sp. & Batch & $\begin{array}{l}\text { Sterile } \\
\text { synthetic }\end{array}$ & $\begin{array}{l}\text { Constant } \\
\text { reinjections of air } \\
\text { Constant } \\
\text { reinjections of air } \\
\text { amended with 30\% } \\
\mathrm{CO}_{2}\end{array}$ & $16: 08$ & $\begin{array}{l}0.12 \\
0.21\end{array}$ & $\begin{array}{l}25 \\
114\end{array}$ & $\begin{array}{l}39 \\
207\end{array}$ & $\begin{array}{l}\text { Swarnalatha et al. } \\
\text { (2015) }\end{array}$ \\
\hline Kirchneriella cornuta & & & $\begin{array}{l}\text { Constant } \\
\text { reinjections of air } \\
\text { Constant } \\
\text { reinjections of air } \\
\text { amended with 30\% } \\
\mathrm{CO}_{2}\end{array}$ & & $\begin{array}{l}0.2 \\
0.26\end{array}$ & $\begin{array}{l}37 \\
109\end{array}$ & $\begin{array}{l}63 \\
198\end{array}$ & \\
\hline Acutodesmus sp. & & & $\begin{array}{l}\text { Constant } \\
\text { reinjections of air } \\
\text { Constant } \\
\text { reinjections of air }\end{array}$ & & $\begin{array}{l}0.18 \\
0.25\end{array}$ & $\begin{array}{l}32 \\
103\end{array}$ & $\begin{array}{l}47 \\
186\end{array}$ & \\
\hline
\end{tabular}


Table 1 (continued)

\begin{tabular}{|c|c|c|c|c|c|c|c|c|}
\hline Microalga & Reactor type & $\begin{array}{l}\text { Culturing } \\
\text { media }\end{array}$ & $\begin{array}{l}\text { Gas feeding and } \\
\text { composition }(\% \mathrm{v} / \mathrm{v})\end{array}$ & Photoperiod & $\mu\left(\mathrm{d}^{-1}\right)$ & $\begin{array}{l}\text { Cell } \\
\text { productivity } \\
\left(\mathrm{mg} \mathrm{L}^{-1} \mathrm{~d}^{-1}\right)\end{array}$ & $\begin{array}{l}\mathrm{CO}_{2} \\
\text { assimilation } \\
\text { rate } \\
\left(\mathrm{mg} \mathrm{L}^{-1} \mathrm{~d}^{-1}\right) \\
\end{array}$ & References \\
\hline & & & $\begin{array}{l}\text { amended with } 30 \% \\
\mathrm{CO}_{2}\end{array}$ & & & & & \\
\hline \multirow[t]{2}{*}{ N. gaditana } & \multirow[t]{2}{*}{ Continuous } & \multirow[t]{2}{*}{ Synthetic } & $\begin{array}{l}\text { Constant aeration } \\
\text { with synthetic } \\
\text { biogas }\left(30 \% \mathrm{CO}_{2} ;\right. \\
\left.70 \% \mathrm{~N}_{2}\right)\end{array}$ & \multirow[t]{2}{*}{24} & - & 100 & 189 & \multirow[t]{2}{*}{ Meier et al. (2015) } \\
\hline & & & $\begin{array}{l}\text { Constant aeration } \\
\text { with raw biogas } \\
\left(72 \pm 2 \% \mathrm{CH}_{4} \text {; }\right. \\
\left.28 \pm 2 \% \mathrm{CO}_{2}\right)\end{array}$ & & - & 30 & $56.4^{\mathrm{a}}$ & \\
\hline \multirow[t]{4}{*}{ Chlorella sp. } & \multirow[t]{4}{*}{ Batch } & \multirow{4}{*}{$\begin{array}{l}\text { Sterile } \\
\text { diluted } \\
\text { domestic } \\
\text { digestate }\end{array}$} & Headspace & \multirow[t]{4}{*}{$12: 12$} & - & $37.4^{\mathrm{c}}$ & $70.4^{\mathrm{a}}$ & \multirow[t]{4}{*}{ Zhao et al. (2013) } \\
\hline & & & containing biogas & & - & $45.7^{c}$ & $85.9^{\mathrm{a}}$ & \\
\hline & & & $\left(67.6 \% \mathrm{CH}_{4} ; 28.4 \%\right.$ & & - & $52.5^{c}$ & $98.7^{\mathrm{a}}$ & \\
\hline & & & $\begin{array}{l}\mathrm{CO}_{2} ; 0.7 \% \mathrm{O}_{2} \\
\left.\mathrm{H}_{2} \mathrm{~S}<50 \mathrm{ppmv}\right)\end{array}$ & & - & $58.6^{c}$ & $110^{\mathrm{a}}$ & \\
\hline \multirow[t]{2}{*}{ Chlorella sp. } & \multirow[t]{2}{*}{ Batch } & \multirow[t]{2}{*}{ Synthetic } & $\begin{array}{l}\text { Intermitent aeration } \\
\text { with }\left(70 \% \mathrm{CH}_{4} ; 20 \%\right. \\
\mathrm{CO}_{2} ; 1 \% \mathrm{O}_{2} ; \\
\mathrm{H}_{2} \mathrm{~S}<100 \text { ppmv) }\end{array}$ & \multirow[t]{2}{*}{24} & - & 250 & $470^{\mathrm{a}}$ & \multirow[t]{2}{*}{$\begin{array}{l}\text { Sirikulrat and } \\
\text { Koonaphapdeelert } \\
(2013)\end{array}$} \\
\hline & & & $\begin{array}{l}\text { Intermitent aeration } \\
\text { with }\left(70 \% \mathrm{CH}_{4} ; 20 \%\right. \\
\mathrm{CO}_{2} ; 1 \% \mathrm{O}_{2} ; \\
\left.\mathrm{H}_{2} \mathrm{~S}<100 \text { ppmv }\right)\end{array}$ & & - & 190 & $357.2^{\mathrm{a}}$ & \\
\hline S. obliquus & \multirow[t]{3}{*}{ Batch } & \multirow{3}{*}{$\begin{array}{l}\text { Sterile } \\
\text { diluted } \\
\text { domestic } \\
\text { digestate }\end{array}$} & Headspace & \multirow[t]{3}{*}{$12: 12$} & - & 56.6 & $106.4^{\mathrm{a}}$ & \multirow{3}{*}{$\begin{array}{l}\text { Ouyang et al. } \\
(2015)\end{array}$} \\
\hline Chlorella sp. & & & containing biogas & & - & 50.3 & $94.5^{\mathrm{a}}$ & \\
\hline S. bibraianum & & & $\begin{array}{l}\left(61.8 \% \mathrm{CH}_{4} ; 35.3 \%\right. \\
\mathrm{CO}_{2} ; 0.3 \% \mathrm{O}_{2} ; \\
\left.\mathrm{H}_{2} \mathrm{~S}<50 \mathrm{ppmv}\right)\end{array}$ & & - & 47.6 & $89.5^{\mathrm{a}}$ & \\
\hline \multirow{4}{*}{$\begin{array}{l}\text { Chlorella sp., Microspora } \\
\text { sp., Pseudanabaena sp., } \\
\text { Stigeoclonium sp., } \\
\text { Planktolyngbya sp. and } \\
\text { Geitlerinema sp. }\end{array}$} & \multirow{4}{*}{$\begin{array}{l}\text { High rate algal } \\
\text { pond connected } \\
\text { to an external } \\
\text { biogas absorption } \\
\text { column }\end{array}$} & \multirow{4}{*}{$\begin{array}{l}\text { Vinasse } \\
\text { digestate }\end{array}$} & No aeration & \multirow[t]{4}{*}{$16: 08$} & - & $17.6^{\mathrm{b}}$ & $33^{\mathrm{a}}$ & \multirow[t]{4}{*}{ Serejo et al. (2015) } \\
\hline & & & $\begin{array}{l}\text { Constant aeration } \\
\text { with synthetic } \\
\text { biogas }\left(30 \% \mathrm{CO}_{2} \text {; }\right. \\
\left.70 \% \mathrm{~N}_{2}\right)\end{array}$ & & - & $47.3^{\mathrm{b}}$ & $89^{a}$ & \\
\hline & & & $\begin{array}{l}\text { Constant aeration } \\
\text { with synthetic } \\
\text { biogas }\left(29.5 \% \mathrm{CO}_{2} \text {; }\right. \\
5000 \text { ppmv } \mathrm{H}_{2} \mathrm{~S} ; 70 \% \\
\left.\mathrm{~N}_{2}\right)\end{array}$ & & - & $65^{\mathrm{b}}$ & $122^{\mathrm{a}}$ & \\
\hline & & & $\begin{array}{l}\text { Constant aeration } \\
\text { with sintetic biogas } \\
\left(29.5 \% \mathrm{CO}_{2} ;\right. \\
5000 \mathrm{ppmv}^{\mathrm{H}} \mathrm{S} ; 70 \% \\
\left.\mathrm{~N}_{2}\right)\end{array}$ & & - & $81^{\mathrm{b}}$ & $152.4^{\mathrm{a}}$ & \\
\hline \multirow{4}{*}{$\begin{array}{l}\text { Spirulina platensis, } \\
\text { Phormidium sp., } \\
\text { Oocystis sp. and } \\
\text { Microspora sp. }\end{array}$} & \multirow{4}{*}{$\begin{array}{l}\text { High rate algal } \\
\text { pond connected } \\
\text { to an external } \\
\text { biogas absorption } \\
\text { column }\end{array}$} & \multirow[t]{3}{*}{ Synthetic } & No aeration & \multirow[t]{4}{*}{24} & & $45.2^{\mathrm{b}}$ & $85^{\mathrm{a}}$ & \multirow{4}{*}{ Bahr et al. (2014) } \\
\hline & & & $\begin{array}{l}\text { Constant aeration } \\
\text { with synthetic } \\
\text { biogas }\left(30 \% \mathrm{CO}_{2} ; \mathrm{H}_{2} \mathrm{~S}\right. \\
500 \text { ppmv balanced } \\
\left.\text { with } \mathrm{N}_{2}\right)\end{array}$ & & - & $52^{\mathrm{b}}$ & $97.8^{\mathrm{a}}$ & \\
\hline & & & Constant aeration & & - & $52^{\mathrm{b}}$ & $97.8^{\mathrm{a}}$ & \\
\hline & & $\begin{array}{l}\text { Domestic } \\
\text { digestate }\end{array}$ & $\begin{array}{l}\text { with synthetic } \\
\text { biogas }\left(30 \% \mathrm{CO}_{2} ; \mathrm{H}_{2} \mathrm{~S}\right. \\
5000 \text { ppmv balanced } \\
\left.\text { with } \mathrm{N}_{2}\right)\end{array}$ & & - & $26.1^{\mathrm{b}}$ & $49^{\mathrm{a}}$ & \\
\hline \multirow[t]{4}{*}{ Scenedesmus spp. } & \multirow[t]{4}{*}{ Batch } & \multirow{4}{*}{$\begin{array}{l}\text { Non-sterile } \\
\text { swine } \\
\text { digestate }\end{array}$} & Open to atmosphere & $12: 12$ & $0.25 \pm 0.1$ & $44.9 \pm 6.9$ & $84.4 \pm 13^{\mathrm{a}}$ & Present study \\
\hline & & & $\begin{array}{l}\text { Biogas in headspace } \\
\left(70.7 \% \mathrm{CH}_{4} ; 26.1 \%\right. \\
\mathrm{CO}_{2} ; 0.23 \% \mathrm{O}_{2} ; \mathrm{H}_{2} \mathrm{~S} \\
\cong 1550 \mathrm{ppmv})\end{array}$ & & $0.5 \pm 0.1$ & $89.4 \pm 2.9$ & $126.1 \pm 12.7$ & \\
\hline & & & Open to atmosphere & 24 & $0.32 \pm 0.1$ & $56.8 \pm 4.6$ & $106.8 \pm 8.7^{\mathrm{a}}$ & \\
\hline & & & $\begin{array}{l}\text { Biogas in headspace } \\
\left(70.7 \% \mathrm{CH}_{4} ; 26.1 \%\right. \\
\mathrm{CO}_{2} ; 0.23 \% \mathrm{O}_{2} ; \mathrm{H}_{2} \mathrm{~S} \\
\cong 1550 \mathrm{ppmv})\end{array}$ & & $0.6 \pm 0.1$ & $141.8 \pm 3.5$ & $219.4 \pm 4.8$ & \\
\hline
\end{tabular}

a Estimated by: $\mathrm{CO}_{2}$ fixation rate $\left({ }_{\mathrm{P} O}\right)=1.88$ [derived from the typical molecular formula of microalgal biomass, $\mathrm{CO}_{0.48} \mathrm{H}_{1.83} \mathrm{~N}_{0.11} \mathrm{P}_{0.01}(\mathrm{Chisti}, 2007) \times$ biomass productivity $\left.\left(\mathrm{mg} \mathrm{L}^{-1} \mathrm{~d}^{-1}\right)\right]$.

b Estimated by: $Q_{\text {out }} \times$ biomass concentration $\left(\mathrm{mg} \mathrm{L}^{-1}\right)$ in $\mathrm{HRAP} /$ total volume.

${ }^{\mathrm{c}}$ Estimated by: $X_{\max }-X_{0}\left(\mathrm{mg} \mathrm{L}^{-1}\right) /$ cultivation time period. 
removal rates. Concomitantly, $\mathrm{CO}_{2}$ and other undesirable compounds present in the biogas, such as the toxic and corrosive $\mathrm{H}_{2} \mathrm{~S}$, could be removed (Bahr et al., 2014), ultimately adding value to filtered biomethane. Xu et al. (2015) demonstrated the effects of desulphurized biogas on increased nutrient removal by axenic culture of microalgae Scenedesmus obliquus. Nonetheless, considering that $\mathrm{H}_{2} \mathrm{~S}$ present in the biogas (up to 5000 ppm; Kao et al., 2012a) could exert some inhibitory effects on microalgae, further studies using raw biogas is warrant to anticipate field scale performance. To illustrate, Chlorella sp. was inhibited when aerated with $\geqslant 100$ ppmv $\mathrm{H}_{2} \mathrm{~S}$ (Kao et al., 2012a). $\mathrm{LD}_{50}$ (lethal dose concentration of $50 \%$ ) of $1.87 \mathrm{mg} \mathrm{H}_{2} \mathrm{~S} \mathrm{~L}^{-1}$ (Küster et al., 2005) and $112.2 \mathrm{mg}$ $\mathrm{H}_{2} \mathrm{~S} \mathrm{~L}^{-1}$ (Gupta et al., 2014) were reported for Scenedesmus vacuolatus and Chlamydomonas sp., respectively. Concentrations of $\mathrm{H}_{2} \mathrm{~S} \geq 8 \mathrm{mg} \mathrm{L}^{-1}$ were reported to inhibit photosynthesis (Shilton, 2005). Yellowstone and Park (1977), demonstrated that $\mathrm{H}_{2} \mathrm{~S}$ impairs $\mathrm{CO}_{2}$ photoreduction and photosystem II in Spirulina labyrinthiformis when exposed from 20 to $41 \mathrm{mg} \mathrm{H}_{2} \mathrm{~S} \mathrm{~L}^{-1}$. The presence of free ammonia in swine wastewater-derived biogas could also affect microalgae growth. Free ammonia concentrations as low as $2.9 \mathrm{mg} \mathrm{L}^{-1}$ could be toxic to some microalgae strains (Abeliovich and Azov, 1976). Besides these inhibitory effects associated with $\mathrm{H}_{2} \mathrm{~S}$ and free ammonia, experiments using non-sterile bacteria rich diluted wastewaters effluents as well as native microalgae polyculture is scarce, and therefore should be explored to best portray field scale scenarios.

Thus, the objective of this work was to investigate the effects of raw swine wastewater-derived biogas on native microalgae polyculture productivity and removal rates of ammonia and phosphate from non-sterile diluted digestate effluent in a lab scale photobioreactor exposed to autotrophic and mixotrophic conditions. A mass balance equation to predict microalgae biomass yield from biogas $\mathrm{CO}_{2}$, total inorganic and organic carbon was developed. The capability of microalgae to remove $\mathrm{CO}_{2}$ and $\mathrm{H}_{2} \mathrm{~S}$ from raw biogas was also investigated as integrated biofiltration strategy.

\section{Methods}

\subsection{Microalgae identification}

The microalgae inoculum used in this work was obtained directly from a field scale facultative open pond used as tertiary treatment process downstream from a biodigestor at the Brazilian Agricultural Research Corporation (EMBRAPA) wastewater treatment facility (Concórdia, SC, Brazil). Microscopical analysis served to provide first evidences of dominant strains present in the inoculum. Microalgae samples were observed under $1000 \times$ magnification using microscopic analysis (Eclipse E200 - Nikon).

A more precise method of microalgae identification was performed by targeting and sequencing $16 \mathrm{~S}$ rRNA gene fragment from chloroplast (Mezzari et al., 2013). DNA was extracted with the MoBio ${ }^{\circledR}$ UltraClean Microbial DNA isolation kit according to manufacturer's instructions (MoBio Laboratories, Solana Beach, CA). PCR amplification of the $16 \mathrm{~S}$ rRNA gene fragments was performed in reactions containing $500 \mathrm{nmol}$ of each universal primer $(1055 \mathrm{~F}$ 50-ATGGCTGTCGTCAGCT-30 and 1392R 50-ACGGGCGGTG TGTAC-30 primers (Ferris and Muyzer, 1996), $2 \times$ PCR Master mix (Quantifast ${ }^{\circledR}$ SYBR $^{\circledR}$ Green PCR kit, Qiagen, CA, USA) and DNA template obtained from the consortium. Thermocycler conditions were: denaturation at $95{ }^{\circ} \mathrm{C}$ for $5 \mathrm{~min}$, followed by 40 cycles of $95^{\circ} \mathrm{C}$ for $10 \mathrm{~s}$ and annealing at $60^{\circ} \mathrm{C}$ for $30 \mathrm{~s}$. PCR products were purified with PureLink ${ }^{\circledR}$ PCR Purification Kit (Invitrogen ${ }^{\circledR}$ ) and cloned into pGEMT Easy Vector Systems (Promega ${ }^{\circledR}$ ) according to manufacturer's protocols. Cloned samples were inserted into JM109 competent cells (Promega, USA), according to manufacturer's instructions using heat shock and plated on selective
Luria-Bertani (LB) medium. Colonies containing plasmids with insert were selected on X-Gal (Sigma, St. Louis, MO) and ampicillin (100 $\mathrm{mg} \mathrm{mL}^{-1}$ ) medium plates. Randomly selected positive colonies were allowed to grow in liquid LB media with ampicillin for plasmidial DNA extraction using a Purelink Quick Plasmid Kit (Invitrogen, USA). Clones were subjected to sequence analysis with an ABI 3730 sequencing system, using an ABI PRISM BigDye Terminator version 3.1 cycle sequencing kit (Applied Biosystems, Foster City, CA). Sequenced products were purified with isopropanol/ ethanol precipitation method prior to analysis (ABI Prism 3130 Avant sequencer, Applied Biosystems). Trimmed sequences were aligned using Ribosomal Database Project (RDP) Infernal Aligner tool. Sequences were compared to each other using Basic Local Alignment Search Tool - BLAST $^{\circledR}$ (blast.ncbi.nlm.nih.gov) (Table S1, supplementary information).

\subsection{Photobioreactor set up}

To evaluate the effects of swine-derived biogas on microalgae growth and nutrient removal, two interconnected $16.9 \mathrm{~L}$ glass made photobioreactors ( $30 \mathrm{~cm}$ high $\times 20 \mathrm{~cm}$ diameter) were used (Fig. 1). The reactors were hermetically closed to atmosphere using rubber stoppers. All lines and fitting were Teflon made to minimize losses through volatilization and diffusion. Each photobioreactor was filled with $8.9 \mathrm{~L}$ of culturing media. The medium was prepared by diluting digestate effluent from a field scale Up-flow Anaerobic Sludge Blank reactor (UASB; EMBRAPA Swine And Poultry, Concórdia, SC, Brazil) in distilled water (6\% v/v). The raw effluent physical-chemical characteristics was $\left(\mathrm{g} \mathrm{L}^{-1}\right)$ : $\mathrm{pH} 7.9$, total solids (3-8), total organic carbon (1.5-6.5), total inorganic carbon (0.8-1), total nitrogen (1.5-2), ammonia-N (0.9-1.5), phosphate-P (0.045-0.06).

Photobioreactors were inoculated with $30 \% \mathrm{v} / \mathrm{v}$ (approximately $70 \mathrm{mg} \mathrm{L}^{-1}$ dry weight biomass) microalgae from stock culture. To determine the effects of photoperiod on microalgae growth kinetics, nutrient removal and biogas purification, two experiments were performed. One experiment was carried out under mixotrophic conditions ( $12 \mathrm{~h}$ : $12 \mathrm{~h}$; light: dark) and the other experiment was maintained under autotrophic conditions ( $24 \mathrm{~h}$ light). The photobioreactors were kept at room temperature $\left(22 \pm 2{ }^{\circ} \mathrm{C}\right)$ and exposed to red light emission diode light (PGL-RBC 2500, Parus) at $630 \mathrm{~nm}$ and $148.5 \mu \mathrm{mol} \mathrm{m}^{-2} \mathrm{~s}^{-1}$ and under continuous

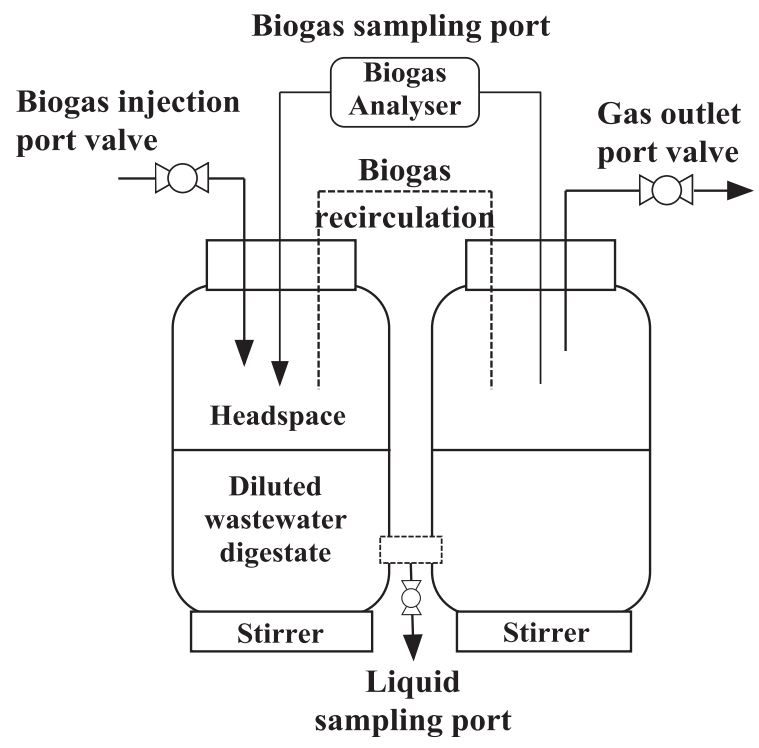

Fig. 1. Schematic of the photobioreactor experimental set up. Dashed lines represent the connections in gas and liquid phase between the containers. 
mixing using a magnetic stirrer. Raw swine wastewater-derived biogas was collected directly from the UASB using specific $10 \mathrm{~L}$ polyethylene bags (Zhao et al., 2013) then immediately transferred to laboratory for injection into photobioreactors. $\mathrm{CH}_{4}, \mathrm{CO}_{2}$ and $\mathrm{H}_{2} \mathrm{~S}$ concentrations in the biogas were: $65-73 \%(\mathrm{v} / \mathrm{v}), 20-25 \%(\mathrm{v} / \mathrm{v})$, and 1800-3100 (ppmv), respectively. The photobioreactors headspace was purged with biogas for approximately $5 \mathrm{~min}$ to eliminate dilution from entrapped atmospheric air. Biogas was constantly reinjected into photobioreactor headspace over time once $\mathrm{CO}_{2}$ concentration was almost completely removed. Three negative control experiments were conducted and prepared identically to previous set up with some exceptions: (1) To discern $\mathrm{CO}_{2}$ assimilation by microalgae from abiotic losses, a photobioreactor was not inoculated with microalgae; (2) to discern the role of bacteria on nutrients removal and biogas purification, a photobioreactor was not inoculated with microalgae and poisoned with sodium azide ( $1 \mathrm{~g} \mathrm{~L}^{-1}$ ) as bacteriostatic; (3) to account for the effects of $\mathrm{CO}_{2}$ on microalgae productivity and nutrients removal rates, a photobioreactor was left open in contact with atmospheric air.

Sodium acetate $\left(1 \mathrm{~g} \mathrm{~L}^{-1}\right)$ was added as an external source of biodegradable carbon into a non-sterile mixotrophic photobioreactor amended biogas after 17 days of experiment. This procedure was used to investigate whether the high biological oxygen demand exerted by bacteria could offset photosynthetic-derived oxygen production in the system.

\subsection{Microalgae yield production estimation}

A carbon mass balance equation (1) was used to estimate microalgae yield in the photobioreactors over time:

$$
\begin{aligned}
& \text { Biomass (as mg } \left.-\mathrm{CL}^{-1}\right) \\
& =\sum_{i=1}^{n} \frac{\left[\left(\mathrm{CO}_{2_{i}}-\mathrm{CO}_{2_{o}}\right)+\left(\mathrm{TOC}_{i}-\mathrm{TOC}_{o}\right)+\left(\mathrm{TIC}_{i}-\mathrm{TIC}_{o}\right)\right] / \mathrm{FCM}}{\mathrm{WV}}
\end{aligned}
$$

where TOC and TIC are total organic and inorganic carbon content $(\mathrm{mg})$ in the culturing media, respectively consumed between time $t_{0}$ and $t_{i}$ (days); WV is the reactor total working volume $(8.9 \mathrm{~L})$; FCM is the fraction of carbon mass (0.5137) derived from microalgae molar basis of $\mathrm{CO}_{0.48} \mathrm{H}_{1.83} \mathrm{~N}_{0.11} \mathrm{P}_{0.01}$ (Chisti, 2007). The equation assumes a plateau at the point where biomass reach stationary phase $\left\{\right.$ i.e., $\left.\ln \left[\left(X / X_{0}\right) / \Delta t \mu_{X}\right] \leqslant 0.03\right\}$. This assumption was based on the fact that under stationary growth phase any additional carbon is used exclusively to maintain intracellular metabolic activities rather than increase biomass (Msanne et al., 2012).

Microalgae biomass productivity $\left(P, \mathrm{mg} \mathrm{L}^{-1} \mathrm{~d}^{-1}\right)$ was calculated with Eq. (2):

$P=\left(X_{t}-X_{0}\right) /\left(t_{x}-t_{0}\right)$

where $X_{t}$ was the biomass concentration $\left(\mathrm{mg} \mathrm{L}^{-1}\right)$ at period corresponding to the end of the exponential growth phase $\left(t_{x}\right)$ and $X_{0}$ the initial biomass concentration $\left(\mathrm{mg} \mathrm{L}^{-1}\right)$ at $t_{0}$ (day).

Microalgae specific growth rate $\left(\mu_{X}, \mathrm{~d}^{-1}\right)$ and $\mathrm{CO}_{2}$ consumption rate $\left(R_{\mathrm{CO}_{2}}, \mathrm{mg} \mathrm{L}^{-1} \mathrm{~d}^{-1}\right)$ were obtained during exponential growth phase according to Eqs. (3) and (4), respectively (Mezzari et al., 2013):

$\mu_{X}=\frac{\ln \left(X_{i} / X_{0}\right)}{t_{2}-t_{1}}$

$R_{\mathrm{CO}_{2}}=\left(S_{i}-S_{0}\right) /\left(t_{2}-t_{1}\right)$

where $X_{i}$ and $X_{0}$ were the biomass concentrations $\left(\mathrm{mg} \mathrm{L}^{-1}\right)$ and $S_{i}$ and $S_{0}$ were substrate $\mathrm{CO}_{2}$ on days $t_{2}$ and $t_{1}$, respectively.

\subsection{Analytical methods}

Liquid samples $(50 \mathrm{~mL})$ were taken over time from the photobioreactor using gas tight syringes through a sampling port valve installed between reactors (Fig. 1). To prevent negative pressure built up inside the photobioreactor, which could interfere with analytical gas measurements, $50 \mathrm{~mL}$ of distilled water was added after every sampling withdrawn. Samples were analyzed daily for $\mathrm{pH}$, temperature ( $\mathrm{pH}-\mathrm{mV}$, Hanna Instruments, Inc.), and dissolved oxygen (DO) (Lutron DO-5519). $\mathrm{P}_{-} \mathrm{PO}_{4}^{3-}$ was quantified by the ascorbic acid colorimetric method (APHA, 2012). Potentiometric analysis using a selective electrode method was used to measure ammonia $\left(\mathrm{N}-\mathrm{NH}_{3}\right)\left(\right.$ APHA, 2012). Nitrite $\left(\mathrm{N}-\mathrm{NO}_{2}^{-}\right)$and nitrate $(\mathrm{N}-$ $\mathrm{NO}_{3}^{-}$) concentrations were determined by flow injection analysis (FIAlab - 2500). Total inorganic (TIC) and organic carbon (TOC) were measured in a TOC analyzer (Multi C/N 2100, Analytik Jena). Gravimetric measurements were used to determine microalgae dry weight $\left(\mathrm{mg} \mathrm{L}^{-1}\right)$ content. A satisfactory correlation $\left(r^{2}=0.97\right)$ between dry matter biomass content (DW) and optical density $\left(\mathrm{OD}_{570}\right)\left(\mathrm{mg}-\mathrm{DW} \mathrm{L} \mathrm{L}^{-1}=536.2 \times \mathrm{OD}_{570 \mathrm{~nm}}-36.89\right)$ was obtained. Thus, microalgae biomass was quantified by spectrophotometer (Hach DR/2000) analysis at $570 \mathrm{~nm}$.

$\mathrm{CO}_{2}, \mathrm{CH}_{4}$ and $\mathrm{H}_{2} \mathrm{~S}$ gases were measured over time using a gas analyzer (GEM 5000-Landtec) installed inline with photobioreactors headspace (Fig. 1). Mass of gases was estimated:

$$
M=[(C \times \mathrm{MWR} \times P \times V) / R \times T]
$$

where $M$ is the mass of a particular gas in the headspace (in $\mathrm{mg}$ ); $C$ is the measured concentration of an individual gas ( $\mathrm{mmol}$ ); MWR is the molecular weight ratio for each particular gas; $P$ is the partial gas pressure (atm); $V$ is the volume of reactor headspace $(8 \mathrm{~L}) ; R$ is the ideal gas constant $\left(0.0821 \mathrm{~atm} . \mathrm{L} \mathrm{mol}^{-1} \mathrm{~K}^{-1}\right)$; and $T$ is the gas temperature in Kelvin.

\subsection{Statistical analysis}

Statistical differences between data set were determined using one-way analysis of variance (ANOVA) with OriginPro 8. A significant difference was considered at the level of $p<0.05$.

\section{Results and discussion}

\subsection{Microalgae growth and nutrient removal rates}

The effects of swine-derived crude biogas on microalgae production and nutrient removal rates in the presence and absence of raw biogas were investigated in photobioreactors under mixotrophic and autotrophic conditions (Fig. 2). The total daily light intensity for mixotrophic and autotrophic conditions were $6.4 \mathrm{~mol} \mathrm{~m}^{-2}$ and $12.8 \mathrm{~mol} \mathrm{~m}^{-2}$, respectively. Although below optimum daily photosynthetic flow for autotrophic conditions, i.e. $17.6 \mathrm{~mol} \mathrm{~m}^{-2}$ (Yan and Zheng, 2013), the results were still useful to distinguish the effects of different photoperiod cultivation methods. The microalgae polyculture used in this work was mainly dominated by Scenedesmus spp. as demonstrated by optical microscopy and 16S rRNA close sequencing analyses (Supplementary information, Table S1). The higher biomass dry weight (DW) concentration of $1.1 \pm 0.2 \mathrm{~g} \mathrm{~L}^{-1}$ was reached in autotrophic as compared to mixotrophic $\left(0.9 \pm 0.1 \mathrm{DW}-\mathrm{g} \mathrm{L}^{-1}\right)$ conditions at 9 and 14 days of cultivation, respectively (Fig. 2). Microalgae growth rates obtained from autotrophic conditions $\left(141.8 \pm 3.5 \mathrm{mg} \mathrm{L}^{-1} \mathrm{~d}^{-1}\right)$ were significantly higher $(p<0.05)$ than that obtained for mixotrophic $\left(89.4 \pm 2.9 \mathrm{mg} \mathrm{L}^{-1} \mathrm{~d}^{-1}\right)$ (Table 1$)$. Independently of photoperiods i.e. autotrophic or mixotrophic, the presence of biogas in headspace significantly improved microalgae growth rate 


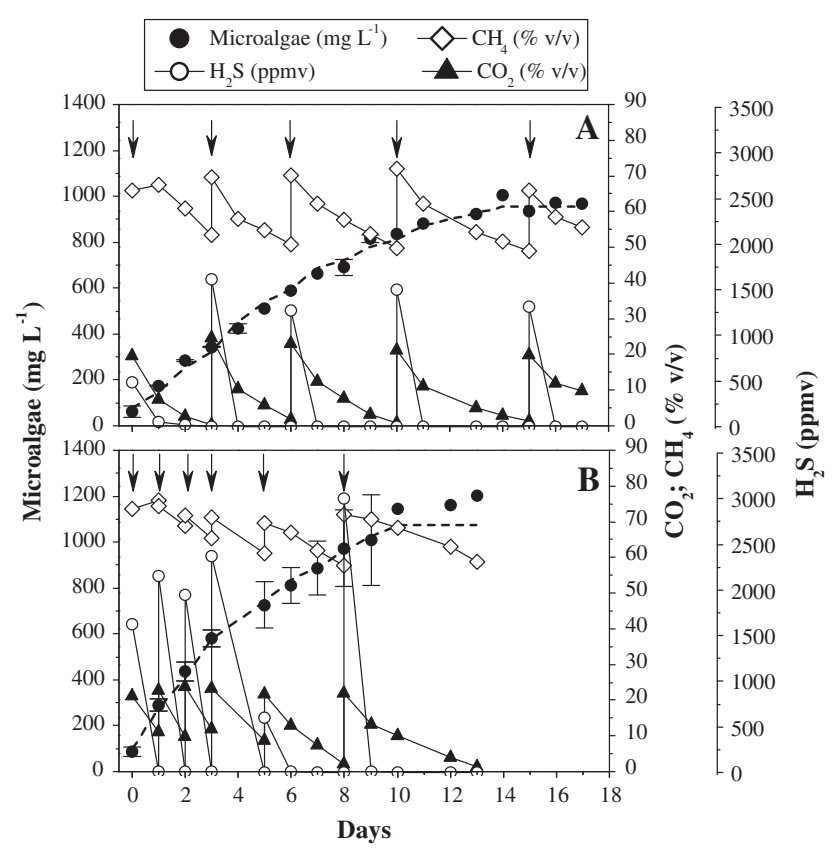

Fig. 2. $\mathrm{CO}_{2}, \mathrm{CH}_{4}, \mathrm{H}_{2} \mathrm{~S}$, and microalgae biomass concentration profiles in the mixotrophic (A) and autotrophic (B) photobioreactors over time. Arrows indicates biogas reinjections. Dashed line shows the microalgae biomass model data fit. Bars depict standard deviation from the mean $(n=2)$.

$(p<0.05)$ compared to photobioreactors exposed to air (Table 1$)$. In the absence of headspace biogas (negative control), microalgae biomass concentrations of 0.48 and $0.53 \mathrm{DW}-\mathrm{g} \mathrm{L}^{-1}$ were obtained at 9 and 14 days of cultivation for autotrophic and mixotrophic conditions, respectively. Thus, swine wastewater-derived raw biogas was effective to stimulate microalgae production. These results are in agreement with previous reports showing that higher microalgae biomass concentration, productivity and specific growth rate is achieved in the presence of $\mathrm{CO}_{2}$ above atmospheric concentrations (Table 1). This is because under increased $\mathrm{CO}_{2}$ concentrations, microalgae induces carboxylation and repress the oxygenase activity of Rubisco, resulting in superior microalgal photosynthesis.

Microalgae can play an important role in biological processes associated with bioremediation of wastewaters due to its capability to assimilate organic compounds and nutrients. $\mathrm{P}_{-} \mathrm{PO}_{4}^{3-}$ was completely removed from diluted wastewater in only 3 days, independently from the photoperiod tested (Fig. 3). The complete $\mathrm{P}_{-} \mathrm{PO}_{4}^{3-}$ removal was assumed as a major bottleneck preventing microalgae biomass from reaching higher productivity. Surprisingly, however, when artificially supplementing the diluted wastewater with $30 \mathrm{mg}-\mathrm{P}_{-} \mathrm{PO}_{4}^{3-} \mathrm{L}^{-1}$, the microalgae growth rate $\left(128.8 \pm 2.8 \mathrm{mg} \mathrm{L}^{-1} \mathrm{~d}^{-1}\right)$ did not improve significantly $(p<0.05)$ from the photobioreactor prepared with diluted digestate effluent,

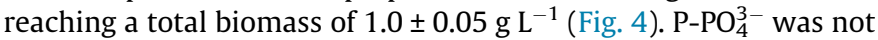
completely consumed up to day $6\left(9.6 \pm 4.3 \mathrm{mg}-\mathrm{P}_{-} \mathrm{PO}_{4}^{3-} \mathrm{L}^{-1}\right)$ remaining in the medium throughout the experimental time frame at lower threshold concentration of $5 \mathrm{mg}-\mathrm{P}_{-} \mathrm{PO}_{4}^{3-} \mathrm{L}^{-1} \cdot \mathrm{P}_{-} \mathrm{PO}_{4}^{3-}$ initial concentrations of $2.3 \pm 0.3$ and $1.8 \pm 1.3 \mathrm{mg} \mathrm{L}^{-1}$ at the mixotrophicand autotrophic-biogas amended photobioreactors, could theoretically produce $232.5 \pm 15.2$ and $213.8 \pm 133.1 \mathrm{mg} \mathrm{L}^{-1}$ of biomass, respectively according to stoichiometry $\mathrm{C}_{1} \mathrm{O}_{0.48} \mathrm{H}_{1.83} \mathrm{~N}_{0.11} \mathrm{P}_{0.01}$. Nonetheless, the measured biomass was much superior to these theoretical values implying that cells were able to adapt to lower nutrients availability (Beuckels et al., 2015). Considering that P is among the crucial elements that limit human increasing population (unlike nitrogen, which can be fixed from atmospheric $\mathrm{N}_{2}$ )
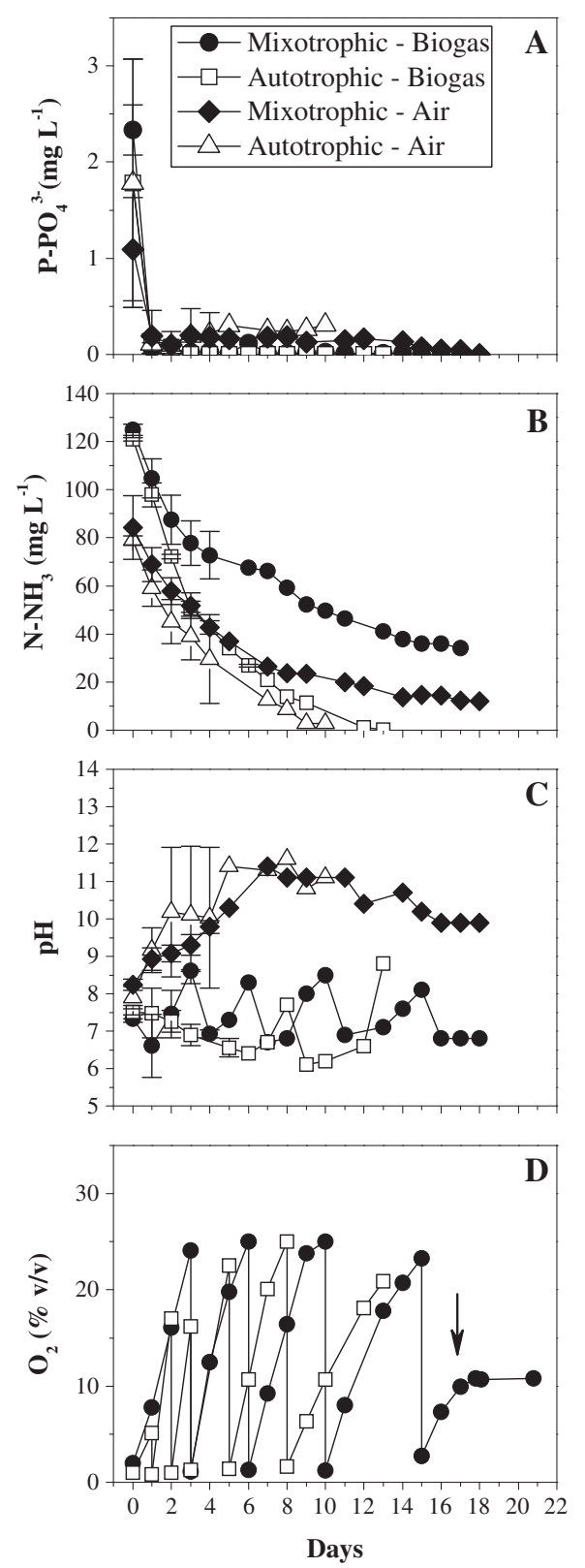

Fig. 3. Effects of photoperiod and headspace biogas on microalgae consumption of $\mathrm{P}_{-} \mathrm{PO}_{4}^{3-}(\mathrm{A})$ and $\mathrm{N}-\mathrm{NH}_{3}(\mathrm{~B}), \mathrm{pH}$ changes (C) and $\mathrm{O}_{2}$ concentration (D) over time. Arrow indicates the addition of sodium acetate $\left(1 \mathrm{~g} \mathrm{~L}^{-1}\right)$ as external carbon source to stimulate heterotrophic bacteria activity and $\mathrm{O}_{2}$ consumption. Bars depict standard deviation from the mean $(n=2)$.

these results suggests that it is possible to rationally and efficiently produce biomass and bioenergy with otherwise lower $\mathrm{P}$ concentrations.

Autotrophic conditions in the presence of biogas showed significant $\mathrm{N}-\mathrm{NH}_{3}$ consumption (Table 2). In the presence of biogas, $\mathrm{N}-\mathrm{NH}_{3}$ removal rates was $21.2 \pm 1.2$ and $14.1 \pm 1.2 \mathrm{mg} \mathrm{L}^{-1} \mathrm{~d}^{-1}$ for autotrophic and mixotrophic conditions, respectively (Table 2). In the absence of biogas, $\mathrm{N}-\mathrm{NH}_{3}$ removal rates of $12.9 \pm 2.0$ and $11.5 \pm 1.3 \mathrm{mg} \mathrm{L}^{-1} \mathrm{~d}^{-1}$ were obtained for autotrophic and mixotrophic conditions, respectively (Table 2). The $\mathrm{N}-\mathrm{NH}_{3}$ removal rates attained in these experiments were lower than previously reported data of $30.4 \mathrm{mg}-\mathrm{N} \mathrm{L}^{-1} \mathrm{~d}^{-1}$ obtained for sterile domestic wastewater under 12:12 h (light:dark) photoperiod (Zhao et al., 2015). This could be attributable to optimum light wavelength used in the latter studies. Satisfactory correlation $\left(r^{2} \geqslant 0.96\right)$ was observed 


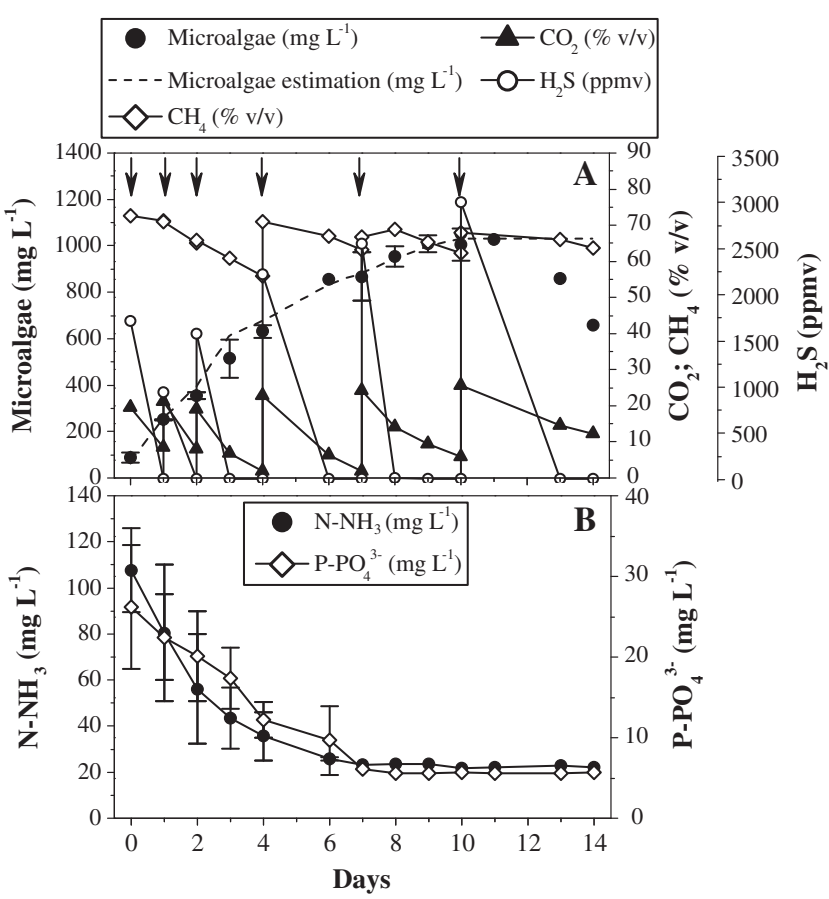

Fig. 4. $\mathrm{CO}_{2}, \mathrm{CH}_{4}, \mathrm{H}_{2} \mathrm{~S}$, and microalgae biomass concentration profiles in autotrophic photobioreactor over time (A). Dashed line shows microalgae biomass model data fit. Microalgae consumption of $\mathrm{P}_{-} \mathrm{PO}_{4}^{3-}$ and $\mathrm{N}-\mathrm{NH}_{3}$ over time (B). $\mathrm{P}-\mathrm{NaH}_{2} \mathrm{PO}_{4}(26 \mathrm{mg}$ $\mathrm{L}^{-1}$ ) was used to supplement $\mathrm{P}$ concentration present in the diluted wastewater digestate. Arrows indicates biogas reinjections. Bars depict standard deviation from the mean $(n=2)$.

Table 2

Ammonia removal rates by microalgae cultivated in the presence and absence of biogas under different photoperiods. Different letters indicate statistically significant differences ( $n=2$, ANOVA, $p<0.05)$.

\begin{tabular}{lllll}
\hline \multirow{6}{*}{} & \multicolumn{3}{l}{ Correlation } & \\
\cline { 3 - 5 } & & $\begin{array}{l}\mathrm{N}-\mathrm{NH}_{2}^{+} \text {removal } \\
\left(\mathrm{mg} \mathrm{L}^{-1} \mathrm{~d}^{-1}\right)\end{array}$ & $\begin{array}{l}\mathrm{N}-\mathrm{NH}_{2}^{+} / \\
\text {microalgae } \\
(\mathrm{mg} / \mathrm{mg})\end{array}$ & $r^{2}$ \\
\hline \multirow{2}{*}{ Biogas } & Autotrophic & $21.2 \pm 1.2^{\mathrm{a}}$ & $0.14 \pm 0.01$ & $0.99 \pm 0.01$ \\
& Mixotrophic & $14.1 \pm 1.2^{\mathrm{b}}$ & $0.15 \pm 0.03$ & $0.98 \pm 0.01$ \\
\multirow{2}{*}{ Air } & Autotrophic & $12.9 \pm 2.0^{\mathrm{b}}$ & $0.16 \pm 0.02$ & $0.96 \pm 0.01$ \\
& Mixotrophic & $11.5 \pm 1.3^{\mathrm{b}}$ & $0.19 \pm 0.07$ & $0.96 \pm 0.04$ \\
\hline
\end{tabular}

between $\mathrm{N}-\mathrm{NH}_{3}$ removals with microalgae growth rate (Table 2). Although the presence and activity of nitrification and denitrification bacteria cannot be discharged (Mezzari et al., 2013), $\mathrm{N}-\mathrm{NH}_{3}$ removal in these experiments was predominantly associated with microalgae assimilation. Removal of $\mathrm{N}^{-\mathrm{NH}_{3}}$ per biomass was higher in photobioreactor exposed to atmospheric air (Table 2). This could be due to increased $\mathrm{pH}$ in these latter reactors (up to $\mathrm{pH} 11.5$; Fig. 3) that led to unaccounted $\mathrm{N}$ volatilization as free ammonia (pKa of 9.26). For instance, free ammonia of $18.1 \pm 3.3$,

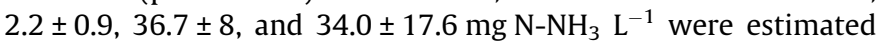
for mixotrophic + biogas, autotrophic + biogas, mixotrophic + air, and autotrophic + air reactors, respectively (Fig. S3, Supplementary information). $\mathrm{N}-\mathrm{NO}_{2}^{-}$and $\mathrm{N}-\mathrm{NO}_{3}^{-}$concentrations present in the diluted digestate culturing medium $\left(\approx 0.5 \mathrm{mg} \mathrm{L}^{-1}\right)$ were rapidly consumed in the first days of experiments (data not shown).

Microalgae photosynthesis and respiration lead to major impacts on carbonate equilibrium chemistry and consequently on $\mathrm{pH}$ changes. The effects of raw biogas on microalgae culturing medium pH are shown (Fig. 3). Unlike photobioreactors open to atmospheric air, the addition of biogas maintained $\mathrm{pH}$ near neutrality. In mixotrophic conditions, it was possible to observe a concomitant decrease in $\mathrm{pH}$ after each biogas reinjection. Photosynthetic $\mathrm{CO}_{2}$ consumption rate was likely exceeding atmospheric- $\mathrm{CO}_{2}$ dissolution rates (Zhao and $\mathrm{Su}, 2014$ ), which in turn exacerbates alkalinization as demonstrated by the increased $\mathrm{pH}$ above 11 in the photobioreactors exposed to atmospheric air.

Overall, microalgae-based wastewater treatment coupled to biogas purification (please see discussion below) could enhance microalge productivity and consequently faster nutrients removal rates. From bioremediation perspectives, this could lead to smaller reactor volumes (and/or lower hydraulic retention times) that would be otherwise needed to achieve equivalent clean up goals. Biogas sustains neutral $\mathrm{pH}$ buffering capacity that is near optimum for efficient microalgae growth and helps minimizing formation of free ammonia and $\mathrm{N}$ losses to atmosphere.

\subsection{Biogas purification}

Removal of undesirable compounds from raw biogas composition by microalgae culturing was evaluated in photobioreactors. $\mathrm{H}_{2} \mathrm{~S}$ at concentrations $\geqslant 150 \mathrm{ppmv}(0.3 \mathrm{vvm})$ (Table 1$)$ has shown to inhibit microalgae growth (Kao et al., 2012b). Inhibitory effects due to $\mathrm{H}_{2} \mathrm{~S}$ may be related to: (1) transport of $\mathrm{CO}_{2}$ in photosynthesis and (2) interference on electron carrier protein of PSII (Photosystem II) for PSI (Photosystem I) (Gupta et al., 2014). Furthermore, compounds derived from the biological oxidation of $\mathrm{H}_{2} \mathrm{~S}$ could also affect microalgae growth. For example, $\mathrm{SO}_{3}^{2-}$ is known to inhibit photosynthetic $\mathrm{CO}_{2}$ fixation in plants due to $\mathrm{SO}_{3}^{2-}$ outcompeting $\mathrm{CO}_{2}$ in rubisco and inhibit mitochondrial ATP production (Malhotra and Hocking, 1976). Contrary to these findings, however, $\mathrm{H}_{2} \mathrm{~S}$ concentrations present in raw biogas up to 3000 ppmv did not exert notable inhibitory effects on microalgae growth (Fig. 2). In fact, microalgae productivity was stimulated in the presence of biogas. This can be verified by comparing microalgae produced in the presence and absence of headspace biogas (Fig. 2 and Table 1 ). $\mathrm{H}_{2} \mathrm{~S}$ was continuously and efficiently (>99\%) removed from photobioreactor headspace even after consecutive biogas reinjections over time. In the non-inoculated poisoned photobioreactor, $\mathrm{H}_{2} \mathrm{~S}$ was removed above 99\% (Fig. 5), supporting the notion that diffusion was the principal mechanism of $\mathrm{H}_{2} \mathrm{~S}$ removal from headspace. In the absence of bacteriostatic and microalgae, $\mathrm{H}_{2} \mathrm{~S}$ was similarly removed but reoccurred at concentrations up to 250 ppmv in the headspace after 3 days (Fig. 5). The appearance of $\mathrm{H}_{2} \mathrm{~S}$ was attributable to formation of anaerobic conditions and increased proliferation and activity of $\mathrm{H}_{2} \mathrm{~S}$ producing sulfate-reducing bacteria. Although beyond the scope of this study, the very high oxidative characteristics of the culturing media due to microalgae photosynthetic $\mathrm{O}_{2}$ production (up to 25\%; Fig. 3) was likely responsible for abiotic (via physical-chemical dissolution-oxidation) or biotic (chemiolitotrophic bacteria that oxidize $\mathrm{H}_{2} \mathrm{~S}$ to sulfate) $\mathrm{H}_{2} \mathrm{~S}$ removal in the system (Bahr et al., 2014).

Free ammonia concentrations ranging from 2.9 to $17.6 \mathrm{mg} \mathrm{L}^{-1}$ were reported to be toxic to $S$. obliquus and Chlorella vulgaris (Abeliovich and Azov, 1976). In this study, free ammonia up to

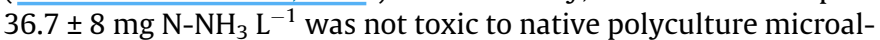
gae (Fig. S3). Since the microalgae utilized in this work was not composed by pure cultures but rather by polyculture dominated by Scenedesmus spp. (Supplementary information, Table S1), it is expected that the free $\mathrm{N}-\mathrm{NH}_{3}$ selected communities physiologically capable to adapt to these high concentrations (Collos and Harrison, 2014). It is worth mentioning that polyculture microalgae inoculum remained dominated by Scenedesmus spp. over the entire experiemtal time frame (Supplementary information, Table S1).

The most relevant rate of $\mathrm{CO}_{2}$ consumption was achieved during microalgae exponential growth phase (up to 10 and 8 days in 


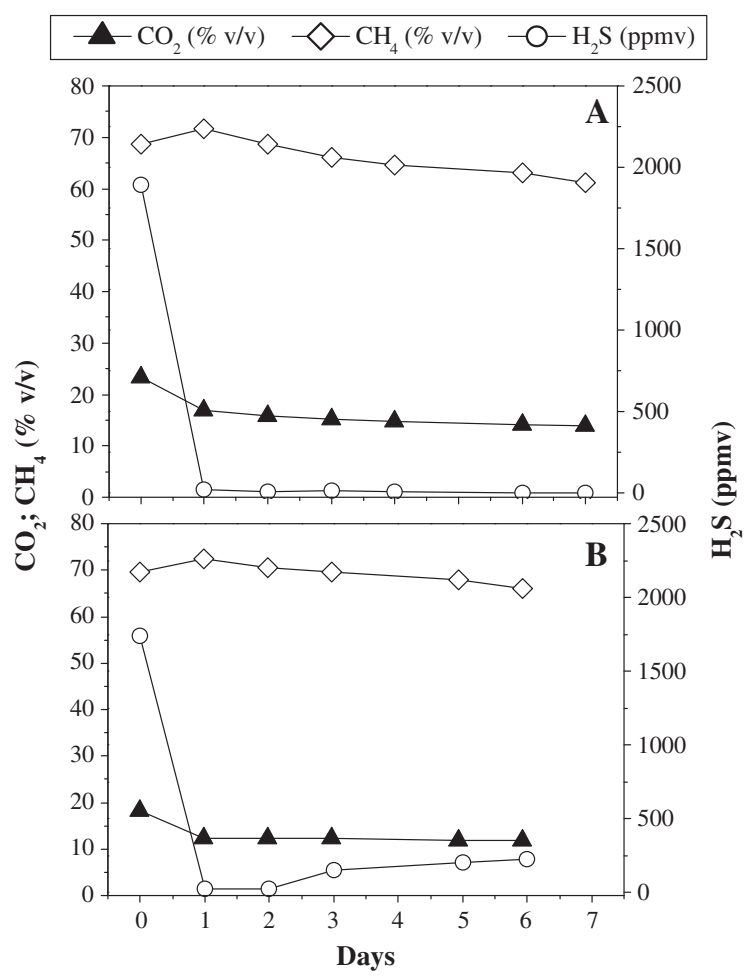

Fig. 5. $\mathrm{CO}_{2}, \mathrm{CH}_{4}$, and $\mathrm{H}_{2} \mathrm{~S}$ concentration profiles in the abiotic control photobioreactor poisoned with bacteriostatic sodium azide $\left(1 \mathrm{~g} \mathrm{~L}^{-1}\right)(\mathrm{A})$ and non sterile control reactor without microalgae inoculum (B).

the mixotrophic and autotrophic photobioreactors, respectively) (Table 1). After that, $\mathrm{CO}_{2}$ consumption rates decreased to 68.5 and $52.9 \mathrm{mg} \mathrm{L}^{-1} \mathrm{~d}^{-1}$ for mixotrophic and autotrophic, respectively as microalgae approached stationary growth phase. At this latter growth stage, $\mathrm{CO}_{2}$ assimilation was probably used to cellular maintenance and accumulation of carbon-rich storage molecules (Msanne et al., 2012). The development of mass balance equations to predict biomass production based on amount of total organic and inorganic carbon consumption over time was demonstrated (Figs. 2 and 4 and Supplementary information, Fig. S1) with strong correlation $\left(r^{2}=0.99\right)$.

The presence of oxygen in the gas composition is undesireable because it can pose an explosion risk. The maximum oxygen concentration allowed in biomethane for commercialization according to Brazilian regulations is $\leqslant 0.5 \%(\mathrm{v} / \mathrm{v})$ (Brazilian National Agency of Petroleum, Natural Gas and Biofuels, 2015). German regulations are not that stringent allowing up to $3 \% \mathrm{v} / \mathrm{v}$ as dry gas for commercial use (Bahr et al., 2014). Therefore, the inherent production of oxygen as result of microalgae-based biogas purification could restrain the commercial usefulness of biomethane unless engineering practices are applied to remove it from the gas stream. Despite satisfactory $\mathrm{CO}_{2}$ and $\mathrm{H}_{2} \mathrm{~S}$ removal from crude biogas, photosynthesis produced $\mathrm{O}_{2}$ up to $\cong 22 \% \mathrm{v} / \mathrm{v}$ (Table 3 ). A linear correlation indicated that $\cong 1$ mol of $\mathrm{O}_{2}$ was produced for each mol of $\mathrm{CO}_{2}$ consumed (Supplementary information, Fig. S2). Mann et al. (2009) recorded microalgae-based $\mathrm{CO}_{2}$ removal of up to $97 \%$ but at the expenses of $\mathrm{O}_{2}$ at $18-23 \%$ in the purified gas stream. Converti et al. (2009) also observed $\mathrm{O}_{2}$ concentrations at $10-24 \%$ during biogas purification by Arthrospira platensis. Contrarily, other studies reported $\mathrm{O}_{2}$ production as low as $0.2 \%$ from the biological filtration of $\mathrm{H}_{2} \mathrm{~S}$ rich- (5,000 ppmv) biogas by microalgae and alkaliphilic bacterial communities (Table 1) (Bahr et al., 2014). The high $\mathrm{H}_{2} \mathrm{~S}$ concentration in this latter study served to exacerbate the oxygen demand required for biological oxidation of $\mathrm{H}_{2} \mathrm{~S}$ to sulfate which requires $2 \mathrm{~mol}$ of $\mathrm{O}_{2}$ per mol of $\mathrm{H}_{2} \mathrm{~S}$. Reduction of $\mathrm{O}_{2}$ in filtered biogas to maximum of $1-1.2 \%$ is possible. In this case, a more complex two-stage approaches under optimized operational conditions that favors gas/liquid volumetric mass transfer coefficient between an absorption column and a photobioreactor is used (Meier et al., 2015; Serejo et al., 2015). However, less complex approaches should also be explored in attempt to overcome $\mathrm{O}_{2}$ levels in the filtered biogas. In this regard, easily biodegradable acetate was added in the mixotrophic photobioreactor on day 17 (Fig. 3) as bacterial carbon source to induce a high BOD in the system. The addition of acetate stimulated heterotrophic bacteria and controlled $\mathrm{O}_{2}$ concentration from increasing in the system, even during light period where photosynthesis activity is higher. Therefore, it is plausible to assume that $\mathrm{O}_{2}$ can be diminished on late stages of the filtering process by simply controlling the input of organic-rich digestate wastewater effluent.

$\mathrm{CO}_{2}$ and $\mathrm{CH}_{4}$ concentration profiles remained constant over time on negative control experiments prepared either in the absence of microalgae or poisoned with bacteriostatic sodium azide (Fig. 5). This indicated that abiotic losses through volatilization or sampling flaws were negligible. Unfortunately, $\mathrm{CH}_{4}$ concentrations were observed to continuously decrease over time and after biogas reinjections (Figs. 2 and 4 ). $\mathrm{CH}_{4}$ removal rates of $52.3 \pm 28.1$ and $30.4 \pm 5 \mathrm{mg} \mathrm{L}^{-1} \mathrm{~d}^{-1}$ were achieved in autotrophic and mixotrophic experiments, respectively (Table 3 ). This represented a $\mathrm{CH}_{4}$ loss of $15.3 \pm 7.1$ and $18.2 \pm 9.2 \% \mathrm{v} / \mathrm{v}$ in autotrophic and mixotrophic experiments, respectively. Consumption of $\mathrm{CH}_{4}$ by methanotrophic bacteria decreases the energy value of the filtered biogas. Although beyond the scope of this study, it is very likely that $\mathrm{CH}_{4}$ removal in the photobioreactors was linked to microalgae stimulation of aerobic conditions and development of methanotrophic activity (Ge et al., 2014). Thus, whereas most studies focused on filtration of biogas using sterile-microalgae culturing systems (Table 1), maintenance of sterile conditions at field scale operations can be costly and difficult to maintain.

Table 3

Biogas composition changes before and after biofiltration by microalgae. Average \pm standard deviation for each biogas injection.

\begin{tabular}{|c|c|c|c|c|c|}
\hline \multirow[t]{2}{*}{ Photoperiod } & & \multirow[t]{2}{*}{ Raw biogas } & \multirow[t]{2}{*}{ Purified biogas } & \multicolumn{2}{|c|}{$\begin{array}{l}\text { Regulatory requirements for } \\
\text { commercialization }\end{array}$} \\
\hline & & & & Brazilian & European \\
\hline Mixotrophic & $\begin{array}{l}\mathrm{CH}_{4}(\% \mathrm{v} / \mathrm{v}) \\
\mathrm{CO}_{2}(\% \mathrm{v} / \mathrm{v}) \\
\mathrm{O}_{2}(\% \mathrm{v} / \mathrm{v}) \\
\mathrm{H}_{2} \mathrm{~S}(\mathrm{ppmv})\end{array}$ & $\begin{array}{r}68.7 \pm 2.8 \\
21.6 \pm 2.2 \\
1.7 \pm 0.7 \\
1237.4 \pm 443.2\end{array}$ & $\begin{array}{r}50.4 \pm 1.9 \\
1.2^{\mathrm{a}} \pm 0.7 \\
21.6 \pm 6.1 \\
0.4 \pm 0.9\end{array}$ & $\begin{array}{l}\geqslant 96.5 \\
\leqslant 3 \\
\leqslant 0.5 \\
\leqslant 10\end{array}$ & $\begin{array}{l}\geqslant 85 \\
\leqslant 6 \\
\leqslant 3(\text { dry }) \\
\leqslant 7\end{array}$ \\
\hline Autotrophic & $\begin{array}{l}\mathrm{CH}_{4}(\% \mathrm{v} / \mathrm{v}) \\
\mathrm{CO}_{2}(\% \mathrm{v} / \mathrm{v}) \\
\mathrm{O}_{2}(\% \mathrm{v} / \mathrm{v}) \\
\mathrm{H}_{2} \mathrm{~S}(\mathrm{ppmv})\end{array}$ & $\begin{array}{r}72.1 \pm 1.7 \\
22.5 \pm 1.0 \\
1.2 \pm 0.3 \\
1950.5 \pm 803.9\end{array}$ & $\begin{array}{r}64.7 \pm 6.9 \\
7.5^{\mathrm{a}} \pm 4.6 \\
17.8 \pm 7.0 \\
5.0 \pm 4.5\end{array}$ & & \\
\hline
\end{tabular}

\footnotetext{
${ }^{\text {a }}$ Complete removal of $\mathrm{CO}_{2}$ can be obtained by a small increase in retention time.
} 
Overall, as shown here, microalgae-based wastewater treatment coupled to biogas purification seems to be a promising alternative to boost nutrient removal while producing simultaneously valuable biomass feedstock and purified biogas as renewable sources of energies at remote agricultural scenarios.

\section{Conclusions}

Increased microalgae yields were obtained under autotrophic conditions and biogas. $\mathrm{N}$ removal rate was significantly faster in the presence of biogas and autotrophic conditions. Biogas buffered $\mathrm{pH}$ and minimized $\mathrm{N}$ volatilization. $\mathrm{H}_{2} \mathrm{~S}$ up to $3000 \mathrm{ppm}$ was completely removed. $\mathrm{CO}_{2}$ assimilation of up to $94.5 \% \mathrm{v} / \mathrm{v}$ and $\mathrm{CH}_{4}$ losses of up to $18 \% \mathrm{v} / \mathrm{v}$ were measured in the filtered biogas. Satisfactory correlation was obtained between total carbon and biomass. Addition of acetate into culturing medium controlled $\mathrm{O}_{2}$ in the filtered biogas. The commercial applicability of purified biogas is critically dependent on system capacity to remove $\mathrm{O}_{2}$ as well as to minimize $\mathrm{CH}_{4}$ losses.

\section{Acknowledgements}

Authors thank financial support from Eletrosul - ANEEL P-14 and Embrapa Swine and Poultry (02.12.08.004.00.05).

\section{A. Supplementary material}

Supplementary data associated with this article can be found, in the online version, at http://dx.doi.org/10.1016/j.biortech.2015.11. 082.

\section{References}

Abeliovich, A., Azov, Y., 1976. Toxicity of ammonia to algae in sewage oxidation ponds. Appl. Environ. Microbiol. 31, 801-806.

Abinandan, S., Shanthakumar, S., 2015. Challenges and opportunities in application of microalgae (Chlorophyta) for wastewater treatment: a review. Renew. Sustain. Energy Rev. 52, 123-132. http://dx.doi.org/10.1016/j.rser.2015.07.086.

APHA, 2012. Standard Methods for the Examination for Water and Wastewater, 22nd ed.

Bahr, M., Díaz, I., Dominguez, A., González Sánchez, A., Muñoz, R., 2014. Microalgalbiotechnology as a platform for an integral biogas upgrading and nutrient removal from anaerobic effluents. Environ. Sci. Technol. 48, 573-581. http://dx. doi.org/10.1021/es403596m.

Beuckels, A., Smolders, E., Muvlaert, K., 2015. Nitrogen availability influences phosphorus removal in microalgae-based wastewater treatment. Water Res. 77, 98-106. http://dx.doi.org/10.1016/j.watres.2015.03.018.

Cheng, I., Xu, J., Huang, Y., Li, Y., Zhou, I., Cen, K., 2015. Growth optimisation of microalga mutant at high $\mathrm{CO}_{2}$ concentration to purify undiluted anaerobic digestion effluent of swine manure. Bioresour. Technol. 177, 240-246. http:// dx.doi.org/10.1016/i.biortech.2014.11.099.

Chisti, Y., 2007. Biodiesel from microalgae. Biotechnol. Adv. 25, 294-306. http://dx. doi.org/10.1016/j.tibtech.2007.12.002.

Collos, Y., Harrison, P.J., 2014. Acclimation and toxicity of high ammonium concentrations to unicellular algae. Mar. Pollut. Bull. 80, 8-23. http://dx.doi. org/10.1016/j.marpolbul.2014.01.006.

Converti, A., Oliveira, R.P.S., Torres, B.R., Lodi, A., Zilli, M., 2009. Biogas production and valorization by means of a two-step biological process. Bioresour. Technol. 100, 5771-5776. http://dx.doi.org/10.1016/i.biortech.2009.05.072.

Ferris, M.J., Muyzer, G., 1996. Denaturing gradient gel electrophoresis profiles of $16 \mathrm{~S}$ rRNA-defined populations inhabiting a hot spring microbial mat community. Appl. Environ. Microbiol. 62, 340-346.

Fuchsz, M., Kohlheb, N., 2015. Comparison of the environmental effects of manureand crop-based agricultural biogas plants using life cycle analysis. J. Clean. Prod. 86, 60-66. http://dx.doi.org/10.1016/j.jclepro.2014.08.058.

Ge, X., Yang, L., Sheets, J.P., Yu, Z., Li, Y., 2014. Biological conversion of methane to liquid fuels: status and opportunities. Biotechnol. Adv. 32, 1460-1475. http:// dx.doi.org/10.1016/j.biotechadv.2014.09.004.
Gupta, E., Dooley, F.D., Ward, P.D., 2014. Evolutionary legacy response observed in algae and bryophytes following hydrogen sulfide administration. Toxicol. Environ. Chem. $\quad$ 96, $\quad \underline{442-450 .} \quad \underline{\text { http://dx.doi.org/10.1080/ }}$ 02772248.2014 .944353$.

Ji, F., Liu, Y., Hao, R., Li, G., Zhou, Y., Dong, R., 2014. Biomass production and nutrients removal by a new microalgae strain Desmodesmus sp. in anaerobic digestion wastewater. Bioresour. Technol. 161, 200-207. http://dx.doi.org/10.1016/j. biortech.2014.03.034.

Kao, C.Y., Chiu, S.Y., Huang, T.T., Dai, L., Hsu, L.K., Lin, C.S., 2012a. Ability of a mutant strain of the microalga Chlorella sp. to capture carbon dioxide for biogas upgrading. Appl. Energy 93, 176-183. http://dx.doi.org/10.1016/j. apenergy.2011.12.082.

Kao, C.Y., Chiu, S.Y., Huang, T.T., Dai, L., Wang, G.H., Tseng, C.P., Chen, C.H., Lin, C.S., 2012b. A mutant strain of microalga Chlorella sp. for the carbon dioxide capture from biogas. Biomass Bioenergy 36, 132-140. http://dx.doi.org/10.1016/j. biombioe.2011.10.046.

Küster, E., Dorusch, F., Altenburger, R., 2005. Effects of hydrogen sulfide to Vibrio fischeri, Scenedesmus vacuolatus, and Daphnia magna. Environ. Toxicol. Chem. 24, 2621-2629. http://dx.doi.org/10.1897/04-546R.1.

Malhotra, S.S., Hocking, D., 1976. Biochemical and cytological effects of sulphur dioxide on plant metabolism. New Phytol. 76, 227-237.

Mann, G., Schlegel, M., Sakalauskas, R.S.A., 2009. Biogas-conditioning with microalgae. Agron. Res. 7, 33-38.

Meier, L., Pérez, R., Azócar, L., Rivas, M., Jeison, D., 2015. Photosynthetic $\mathrm{CO}_{2}$ uptake by microalgae: an attractive tool for biogas upgrading. Biomass Bioenergy 73 , 102-109. http://dx.doi.org/10.1016/j.biombioe.2014.10.032.

Mezzari, M.P., da Silva, M.L.B., Nicoloso, R.S., Ibelli, A.M.G., Bortoli, M., Viancelli, A., Soares, H.M., 2013. Assessment of $\mathrm{N}_{2} \mathrm{O}$ emission from a photobioreactor treating ammonia-rich swine wastewater digestate. Bioresour. Technol. 149, 327-332. http://dx.doi.org/10.1016/j.biortech.2013.09.065.

Msanne, J., Xu, D., Konda, A.R., Casas-Mollano, J.A., Awada, T., Cahoon, E.B., Cerutti, H., 2012. Metabolic and gene expression changes triggered by nitrogen deprivation in the photoautotrophically grown microalgae Chlamydomonas reinhardtii and Coccomyxa sp. C-169. Phytochemistry 75, 50-59. http://dx.doi. org/10.1016/i.phytochem.2011.12.007.

Ouyang, Y., Zhao, Y., Sun, S., Hu, C., Ping, L., 2015. Effect of light intensity on the capability of different microalgae species for simultaneous biogas upgrading and biogas slurry nutrient reduction. Int. Biodeterior. Biodegradation 104, 157163. http://dx.doi.org/10.1016/j.ibiod.2015.05.027.

Serejo, M.L., Posadas, E., Boncz, M.A., Blanco, S., García-Encina, P., Muñoz, R., 2015. Influence of biogas flow rate on biomass composition during the optimization of biogas upgrading in microalgal-bacterial processes. Environ. Sci. Technol. 150212112813001. http://dx.doi.org/10.1021/es5056116.

Shilton, A.N., 2005. Pond Treatment Technology. IWA Publishing.

Sirikulrat, K., Koonaphapdeelert, S., 2013. Capture of carbon dioxide in biogas by using Chlorella sp. Photobioreactor, 209-215.

Swarnalatha, G.V., Hegde, N.S., Chauhan, V.S., Sarada, R., 2015. The effect of carbon dioxide rich environment on carbonic anhydrase activity, growth and metabolite production in indigenous freshwater microalgae. Algal Res. 9, 151-159. http://dx.doi.org/10.1016/j.algal.2015.02.014.

Wang, Z., Zhao, Y., Ge, Z., Zhang, H., Sun, S., 2015. Selection of microalgae for simultaneous biogas upgrading and biogas slurry nutrient reduction under various photoperiods. J. Chem. Technol. Biotechnol. http://dx.doi.org/10.1002/ jctb.4788.

Xu, J., Zhao, Y., Zhao, G., Zhang, H., 2015. Nutrient removal and biogas upgrading by integrating freshwater algae cultivation with piggery anaerobic digestate liquid treatment. Appl. Microbiol. Biotechnol. http://dx.doi.org/10.1007/s00253-015$6537-\mathrm{x}$.

Yan, C., Zheng, Z., 2013. Performance of photoperiod and light intensity on biogas upgrade and biogas effluent nutrient reduction by the microalgae Chlorella sp. Bioresour. Technol. 139, 292-299. http://dx.doi.org/10.1016/j. biortech.2013.04.054.

Yellowstone, I.I., Park, N., 1977. The Effect of Sulfide on the Blue-Green Algae of Hot Springs Introduction 105, 79-105.

Zhao, B., Su, Y., 2014. Process effect of microalgal-carbon dioxide fixation and biomass production: a review. Renew. Sustain. Energy Rev. 31, 121-132. http:// dx.doi.org/10.1016/j.rser.2013.11.054.

Zhao, Y., Sun, S., Hu, C., Zhang, H., Xu, J., Ping, L., 2015. Performance of three microalgal strains in biogas slurry purification and biogas upgrade in response to various mixed light-emitting diode light wavelengths. Bioresour. Technol. 187, 338-345. http://dx.doi.org/10.1016/j.biortech.2015.03.130.

Zhao, Y., Wang, J., Zhang, H., Yan, C., Zhang, Y., 2013. Effects of various LED light wavelengths and intensities on microalgae-based simultaneous biogas upgrading and digestate nutrient reduction process. Bioresour. Technol. 136, 461-468. http://dx.doi.org/10.1016/j.biortech.2013.03.051.

Zhou, W., Chen, P., Min, M., Ma, X., Wang, J., Griffith, R., Hussain, F., Peng, P., Xie, Q. Li, Y., Shi, J., Meng, J., Ruan, R., 2014. Environment-enhancing algal biofuel production using wastewaters. Renew. Sustain. Energy Rev. 36, 256-269. http:/| dx.doi.org/10.1016/j.rser.2014.04.073. 